\title{
Akut alt solunum yolu enfeksiyonu nedeniyle hastaneye yatan çocuklarda Multiplex-PCR ile saptanan enfeksiyöz etkenlerin değerlendirilmesi
}

\author{
Evaluation of infectious factors detected by Multiplex-PCR in hospitalized children \\ due to acute lower respiratory tract infection
}

Gül İrem Kanberoğlu, Elif Güdeloğlu, Özlem Bağ, Çiğdem Ömür Ecevit

Gönderilme tarihi:19.10.2020

Kabul tarihi:11.03.2021

Öz

Giriş: Alt solunum yolu enfeksiyonları, çocuklarda morbidite ve mortaliteden önemli ölçüde sorumludur. Etken gösterilmesi her zaman mümkün olmamakla birlikte, Multiplex-PCR solunum epitelinde yerleşmiş mikroorganizmanın tespitinde kullanılan yeni tetkiklerdendir. Bu çalışmanın amacı; akut alt solunum yolu enfeksiyonu tanısında kullanılan Multiplex-PCR ile saptanan etkenler ve bu etkenlerin klinik, radyolojik ve laboratuar bulguları ile ilişkisinin açıklanmasıdır.

Gereç ve yöntem: Çalışmamızdaki olgulara; İzmir Dr. Behçet Uz Çocuk Hastalıkları ve Cerrahisi Eğitim Araştırma Hastanesi, Çocuk Sağlığı ve Hastalıkları Klinikleri'nde Nisan 2015-Nisan 2017 tarihleri arasındaki hasta dosya ve hastane bilgisayar kayıtlarının incelenmesi sonucu ulaşılmıştır. Bu çalışmada klinik ve laboratuar belirteçlerin etken patojenin türü (virüs ya da bakteri) üzerine olan ilişkisi ile mevsim ve aylara göre etken patojenin dağılımı incelenmiştir.

Bulgular: Çalışmaya dahil edilen toplam hasta sayısı 152 idi. Hastaların 83'ü $(\% 54,6)$ erkek, 69'u

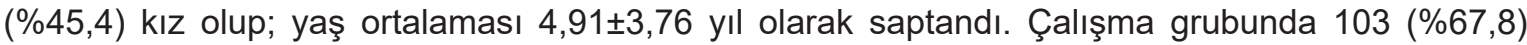
olguya ait örnekte M-PCR pozitif saptandı. Multiplex-PCR'ın en sık pozitif saptandığı yaş aralığı 3 ay-5 yaştır. Multiplex-PCR pozitif olgularda en fazla saptanan etken \%62,13 ile viral etkenler olup, en fazla saptanan virüs \%32 ile Rhinovirüs, 2. sıklıkta Respiratuar sinsityal virüs (RSV) enfeksiyonları $(\% 22,3)$ olmuştur. Bakteriler ise \%37,9 oranında saptanırken en fazla saptanan bakteri \%22,3 ile Streptococcus pneumoniae (S.pneumoniae), 2. sıklıkta Stafilococcus aureus (S.aureus) $(\% 11,6)$ olmuştur. Ateş ve akciğer grafisinde infiltrasyon olan olgularda daha çok bakterilerin etken olduğu görüldü. Her mevsimde virüslerin bakterilerden daha fazla saptandığı görüldü.

Sonuç: Çalışmamızda alt solunum yolu enfeksiyonlarında etken göstermede Multiplex-PCR'ın yüksek oranda (\%67) pozitif olduğu gösterildi. Bu tetkik, viral etkenlerin rol oynadığı alt solunum yolu enfeksiyonlarında; gereksiz antibiyotik kullanımını ve hastanın izlemi sırasında istenen laboratuvar tetkiklerini azaltılmasında önemli rol oynayabilir.

Anahtar kelimeler: Solunum yolu enfeksiyonu, Multiplex-PCR, hastanede yatan çocuk.

Kanberoğlu GI, Güdeloğlu E, Bağ Ö, Ecevit ÇÖ. Akut alt solunum yolu enfeksiyonu nedeniyle hastaneye yatan çocuklarda Multiplex-PCR ile saptanan enfeksiyöz etkenlerin değerlendirilmesi. Pam Tıp Derg 2021;14:604-610.

Abstract

Purpose: Lower respiratory tract infections (LRTI) are significantly responsible for morbidity and mortality in children. Multiplex-PCR (M-PCR) is one of the new tests used to detect the microorganism located in the respiratory epithelium. The aim of this study is to evaluate the microbiologic agents

Gül İ́rem Kanberoğlu, Uzm. Dr. İzmir S.B.Ü. Dr.Behçet Uz Çocuk Hastalıkları ve Cerrahi Eğitim ve Araştırma Hastanesi, Çocuk Sağlığı ve Hastalıkları Anabilim Dalı, İzmir, Türkiye, e-posta: dr.gulirem@gmail.com (https://orcid.org/0000-0003-0070-5089) (Sorumlu Yazar)

Elif Güdeloğlu, Uzm. Dr. İzmir S.B.Ü. Dr.Behçet Uz Çocuk Hastalıkları ve Cerrahi Eğitim ve Araştırma Hastanesi, Çocuk Sağlığı ve Hastalıkları Anabilim Dalı, İzmir, Türkiye, e-posta: drelif55@hotmail.com (https://orcid.org/0000-0002-3818-017X)

Özlem Bağ, Doç. Dr. İzmir S.B.Ü. Dr. Behçet Uz Çocuk Hastalıkları ve Cerrahi Eğitim ve Araştırma Hastanesi, Çocuk Sağlığı ve Hastalıkları Anabilim Dalı, İzmir, Türkiye, e-posta: bagozlem78@yahoo.com (https://orcid.org/0000-0003-2178-4695)

Çiğdem Ömür Ecevit, Doç. Dr. İzmir S.B.Ü. Dr.Behçet Uz Çocuk Hastalıkları ve Cerrahi Eğitim ve Araştırma Hastanesi, Çocuk Sağlığı ve Hastalıkları Anabilim Dalı, Çocuk Gastroenterolojisi Kliniği, İzmir, Türkiye, e-posta: ctecevit@hotmail.com (https://orcid.org/0000-0002-3980-8686) 
determined by M-PCR in the diagnosis of acute LRTI and and explaining the relationship of these factors with clinical, radiological and laboratory findings.

Material and methods: The medical records of pediatric patients hospitalized for acute LRTI in İzmir Dr. Behçet Uz Children's Hospital between April 2015 and April 2017 were evaluated retrospectively. The relationship between clinical and laboratory markers on the type of pathogen and the distribution by season and month were investigated.

Results: The number of the patients in the study group was 152 (M/F: 83/69; mean age: $4.91 \pm 3.76$ years). In the study group, samples of $103(67.8 \%)$ cases were found to be M-PCR positive. The age range in which M-PCR is most frequently found positive was 3 months -5 years. The most common factor in M-PCR $(+)$ cases was viral factors $(62.13 \%)$ and the most common virus was Rhinovirus (32\%), 2nd frequent was Respiratory syncytial virus (RSV) infections (22.3\%). On the other hand, bacteria were detected in $37.9 \%$ of the patients, while Streptococcus pneumoniae (S.pneumoniae) was the most common bacteria (22.3\%), 2nd frequency was Stafilococcus aureus (S.aureus) $(11.6 \%)$. Conclusion: M-PCR was found to be highly positive $(67 \%)$ in documenting a factor in LRTI. Thus, M-PCR may play an important role in reducing the use of unnecessary antibiotics and detailed laboratory tests fort he patient's with LRTI most of which are caused by viral pathogens.

Key words: Respiratory infection, Multiplex-PCR, hospitalized child.

Kanberoglu GI, Gudeloglu E, Bag O, Ecevit CO. Evaluation of infectious factors detected by MultiplexPCR in hospitalized children due to acute lower respiratory tract infection. Pam Med J 2021;14:604610.

\section{Giriş}

Solunum yolu enfeksiyonları, çocuklarda hastaneye yatışlardan ve önemli miktarda morbidite ve mortaliteden sorumludur [1]. Bu tür enfeksiyonların çoğu viral kökenlidir, ancak viral enfeksiyonların genellikle bakteriyel enfeksiyonlardan ayırt edilmesi güçtür [2]. Patojene spesifik olabilecek klinik semptomlar yok denilecek kadar azdır [2]. Bu nedenle, spesifik tanı neredeyse tamamen laboratuvar araştırmasına dayanır [3]. Etiyolojik ajanların erken ve doğru tespit edilmesi ve uygun tedavinin başlatıması mortalite ve morbiditeyi önemli ölçüde azaltmaktadır. Ancak; klinik uygulamada olguların en az yarısında etiyolojik faktör tespit edilmemektedir. Konvansiyonel kültür ve serolojik yöntemlerin uzun sürede sonuç vermesi nedeniyle hastalarda ampirik antibiyotik tedavisi sıklıkla başlanmak zorunda kalınmaktadır $[4,5]$. Çeşitli virüsleri aynı anda hızlıca tanımlayabilen testler, uygun tedavinin başlatılmasına yardımcı olabilir [6]. MultiplexPCR, solunum yolu enfeksiyonlarına neden olan virüslerin ve bakterilerin niteliksel olarak saptanmasında etken patojenleri Multipleks Real-Time PCR reaksiyonu ile belirleyen in vitro bir testtir.
Bu çalışmada amacımız, hastanemiz pediatri kliniklerinde akut alt solunum yolu enfeksiyonu tanısı ile izlenmiş ve Multiplex-PCR yöntemi ile tetkik edilmiş hastaların klinik, radyolojik, laboratuvar bulgularına ek olarak yaş ve mevsim ile Multiplex-PCR sonuçları arasındaki ilişkiyi karşılaştırmaktır.

\section{Gereç ve yöntem}

Çalışmamızdaki akut alt solunum yolu enfeksiyonu tanısı ile yatarak izlenen M-PCR ile tetkik edilmiş, İzmir Dr. Behçet Uz Çocuk Hastalıkları ve Cerrahisi Eğitim Araştırma Hastanesi'nde Nisan 2015-Nisan 2017 tarihleri arasındaki 152 hasta verisine; hastane elektronik kayıtlarının incelenmesi sonucu ulaşıldı.

Multiplex-PCR tetkiki Anatolia Geneworks firmasının Bosphore solunum patojenleri v4 panel kiti ile Montania 4896 isimli cihazında çalışılmıştır. Nazofarengeal sürüntü alınarak çalışılan tetkik 3 günde sonuçlanmaktadır. Solunum yolu örneklerinin alınmasında çubuk kısmı bükülebilir özellikte olan rayon uçlu eküvyonlar kullanıldı. Eküvyon burun deliğinden sokularak nazofarinkse girildi, 5 saniye bekletildikten sonra yavaşça çevrilerek örnek alındı. Bu kit ile saptanabilen etkenler; İnfluenzavirüs A, B ve İnfluenzavirüs A 
alttip H1N1; Parainfluenzavirüsler 1, 2, 3 ve 4; Coronavirüsler NL63, 229E, OC43 ve HKU1; Human metapneumovirüs; Rhinovirüs, Respiratory syncytial virüs (RSV) $A$ ve $B$, Adenovirüs, Enterovirüs, Parechovirus, Bocavirus, Mycoplasma pneumoniae (M.pneumoniae, Chlamydia pneumoniae (C.pneumoniae), Streptococcus pneumoniae (S.pneumoniae), Haemophilus influenzae (H.influenza) tip B, Staphylococcus aureus'dur (S. aureus) [7].

Olgular öncelikle M-PCR pozitif ve negatif olarak iki gruba ayrıldı. Her grup kategorik değişkenler (cinsiyet, ateş, konsolidasyon, mevsim) açısından incelendi. Mevsimler ilkbahar, yaz, sonbahar, kış olarak 4'e ayrılırken her mevsim de kendi içinde aylara bölünerek değerlendirildi. Ateş varlığı, alından kızılötesi ateş ölçer ile ölçülerek $\geq 38^{\circ} \mathrm{C}$ olarak tanımlandı. Konsolidasyon varlığı akciğer grafisi yorumlanarak belirlendi.

Etken gösterebildiğimiz M-PCR (+) hastalar; etken patojenin türüne (virüs, bakteri, virüs+bakteri) göre ayrı ayrı ateş, konsolidasyon, nötrofil/lenfosit oranı, beyaz küre, CRP (C-Reaktif Protein) ve sedimantasyon açısından incelendi.

Elde edilen veriler SPSS (Statistical Program in Social Sciences, IBM, ABD) 24 paket programında bilgisayara aktarıldı ve analiz edildi. Gruplar arasında sayısal değişkenlerin farklılığı Mann Whitney $U$ ve Kruskall Wallis çoklu karşılaştırma yöntemiyle, kategorik değişkenlerin farklıı̆ı ise ki-kare yöntemiyle incelendi. İstatistiksel anlamlılık düzeyi tüm testler için $p<0,05$ değeri olarak kabul edildi. Çalışma için lokal etik kuruldan onay alındı.

\section{Bulgular}

Çalışmaya dahil edilen toplam hasta sayısı 152 idi. Hastaların 83'ü $(\% 54,6)$ erkek, 69'u $(\% 45,4)$ kız olup; yaş ortalaması $4,91 \pm 3,76$ olarak saptandı. Çalışma grubunda $103(\% 67,8)$ olguya ait örnekte M-PCR pozitif saptandı (Tablo 1).

Klinik ve laboratuvar belirteçlere göre etken dağıımı incelendiğinde; M-PCR (+) olan olgularda, ateş sıklığı \%63 iken, PCR ile etken gösterilemeyen olgularda bu oran \%37 olarak saptandı. Ancak fark istatistiksel olarak anlamlı düzeyde değildi $(p=0,080)$. Yine akciğer grafisinde konsolidasyon varlığı M-PCR (+) olgularda, negatif olanlara göre daha sık olduğu görüldü. Ancak fark istatistiksel olarak anlamlı değildi $(p=0,078)$. Mevsimlere göre yapılan değerlendirmede, sonbahar ve kış mevsimlerinde M-PCR (+) saptanma oranı $\% 70$ iken, ilkbahar yaz aylarında bu oranın \%54 olduğu saptandı. Fark istatistiksel olarak anlamlı idi (Tablo 1).

Tablo 1. Bazı demografik ve klinik verilere göre M-PCR pozitiflik oranı

\begin{tabular}{|c|c|c|c|c|}
\hline Hasta Verileri & $\begin{array}{l}\text { M PCR (+) } \\
(n, \%)\end{array}$ & $\begin{array}{l}\text { M PCR (-) } \\
(n, \%)\end{array}$ & Toplam Sayı & ${ }^{*} p$ değeri \\
\hline $\begin{array}{l}\text { Cinsiyet } \\
\text { Erkek } \\
\text { Kız } \\
\text { Ates }\end{array}$ & $\begin{array}{l}55,66 \\
48,47\end{array}$ & $\begin{array}{l}28,34 \\
21,43\end{array}$ & $\begin{array}{l}83 \\
69\end{array}$ & 0,250 \\
\hline$\geq 38$ & 65,63 & 35,37 & 100 & 0,080 \\
\hline Konsolidasyon & & & & \\
\hline Evet & 65,63 & 35,37 & 100 & 0,078 \\
\hline $\begin{array}{l}\text { Mevsim } \\
\text { Sonbahar/Kış } \\
\text { İlkbahar/Yaz }\end{array}$ & $\begin{array}{l}70,76 \\
33,54\end{array}$ & $\begin{array}{l}21,24 \\
28,46\end{array}$ & $\begin{array}{l}91 \\
61\end{array}$ & 0,010 \\
\hline $\begin{array}{l}\text { Yaş Aralığı } \\
\text { 0-3ay } \\
\text { 3ay-5 yaş } \\
>5 \text { yaş }\end{array}$ & $\begin{array}{l}17,11 \\
49,32 \\
37,24\end{array}$ & $\begin{array}{l}12,8 \\
21,14 \\
16,11\end{array}$ & $\begin{array}{l}29 \\
70 \\
53\end{array}$ & 0,06 \\
\hline
\end{tabular}

${ }^{*} p<0,05$ anlamlı kabul edilmiştir (Mann Whıtney U testi kullanılmıştır) 
Klinik, laboratuar ve radyolojik bulgular, M-PCR yöntemi ile gösterilmiş, viral, bakteriyel, viral + bakteriyel etkenlere göre incelendiğinde, ateş ve akciğer grafisinde infiltrasyon olan olgularda daha çok bakterilerin etken olduğu görüldü, fark İstatistiksel olarak anlamlı idi (Tablo 2). M-PCR pozitif tüm gruplarda lökosit sayısının median değeri arasındaki fark
İstatistiksel olarak anlamlı değildi (Tablo 2). Benzer şekilde M- PCR pozitif tüm gruplarda sedimentasyon ve CRP değerleri arasındaki fark istatistiksel olarak anlamlı değildi. Mutlak nötrofil sayısının, mutlak lenfosit sayısına oranı açısından değerlendirildiğinde 3 grup arasında anlamlı fark izlenmedi (Tablo 2).

Tablo 2. Klinik, laboratuvar ve radyolojik bulgulara göre etken dağılımı

\begin{tabular}{|c|c|c|c|c|}
\hline & Virüs $(n=48)$ & $\begin{array}{l}\text { Bakteri } \\
(n=39)\end{array}$ & $\begin{array}{l}\text { Virüs+Bakteri } \\
(n=16)\end{array}$ & ${ }^{*} p$ değeri \\
\hline Ateş n (\%) & $14(29)$ & $35(90)$ & $16(100)$ & 0,020 \\
\hline Konsolidasyon n (\%) & $12(25)$ & $37(75)$ & $16(100)$ & 0,018 \\
\hline${ }^{* *}$ NLO (median) & 2,6 & 5,13 & 4,3 & 0,080 \\
\hline Lökosit (10³/uL) (median) & 12,1 & 12,4 & 14,5 & 0,690 \\
\hline${ }^{\star * *} \operatorname{ESR}(\mathrm{mm} / \mathrm{h})($ median$)$ & 29,5 & 39 & 37 & 0,060 \\
\hline${ }^{* * * *}$ CRP (mg/dl) (median) & 1,89 & 3,60 & 3,5 & 0,770 \\
\hline
\end{tabular}

Tablo 3'de etkenlerin mevsimlere göre dağılımı gösterilmektedir. Buna göre, her mevsimde virüslerin bakterilerden daha fazla saptandığı görüldü. En sık saptanan virüs Rhinovirüs $(\% 33,9)$ olup 2. sıklıkta RSV enfeksiyonları $(\% 22,3)$ idi. Diğer virüsler Bocavirus $(\% 6,8)$, Adenovirus $(\% 2,9)$ idi. En sık saptanan bakteri S.pneumoniae $(\% 22,3)$ olup 2. sıklıkta S.aureus $(\% 11,6)$ idi. 3. sıklıkta saptanan bakteri ise $\% 4,8$ ile M.pneumoniae oldu.

\section{Tartışma}

$\mathrm{Bu}$ çalışmada 152 hastanın 103'ünde $(\% 67,8) \quad$ M-PCR ile solunum patojeni saptanabilmiştir. Literatürde benzer pozitif sonuç yüzdeleri sıklıkla saptanmaktadır (\%17,5, $\% 44, \% 73,5)$ [8-10]. Çalışmamızda M-PCR pozitifliğinin erkekler ve kızlar arasında farklılık göstermediğini bulduk ve bu durum yapılan diğer solunum yolu enfeksiyonu çalışmalarını doğruladı [11, 12]. Viral enfeksiyonlar, çocuklar arasında solunum yolu enfeksiyonlarında önemli bir nedendir. Çalışmamızda akut alt solunum yolu enfeksiyonu tanısı ile izlenen olgularda viral etkenleri saptama oranı, çocuklarda viral etkenlerin \%47-95 oranında bildirildiğini bildiren daha önceki çalışmalarla benzerdir [13-18]. Çalışmamızdaki ko-enfeksiyon oranları, Goka ve ark.'nın [19] viral alt solunum yolu enfeksiyonlarında viral+bakteriyel koenfeksiyon oranları (\%5-62) ile benzer bulunmuştur. PCR kullanan klinik örneklerde bakteri tespit oranı \%41 iken kültür yöntemi ile sadece \%13'tür. Bakteri etkeni saptama oranımız benzer bir çalışma ile yakın oranlarda olacak şekilde \%37,9 idi [20]. MultipleksPCR, konvansiyonel hücre kültürü izolasyonu veya immünofloresans analizi kullanılarak doğrudan tespit ile saptanamayan Rhinovirus, Coronovirus OC43 ve $\mathrm{H}$. metapneumovirus'un saptanmasına izin vermiştir. Bizim çalışmamızda hem viral etkenlerden hem de tek veya çoklu enfeksiyonlarda en çok saptanan etken Rhinovirüsler en sık saptanan etken olup onu sırasıyla RSV, Parainfluenza virüsler ve İnfluenza virüsler izlemektedir. Ülkemizde yapılan çalışmalarda da akut alt solunum yolu enfeksiyonlu çocuklarda RSV, İnfluenza virüs ve Rhinoviruslar sık saptanan etkenler arasında yer almaktadır [21-23]. Dünyada yapılan diğer çalışmalar ile benzer şekilde Rhinovirüs, RSV, Parainfluenza ve İnfluenza virüsden sonra en sık saptanan virüs Bochavirüs olmuştur [24-26].

Solunum yolu enfeksiyonlarının etiyolojisi ve solunum yolu virüs prevalansı farklı çalışmalarda değişiklik gösterir. Amerika 


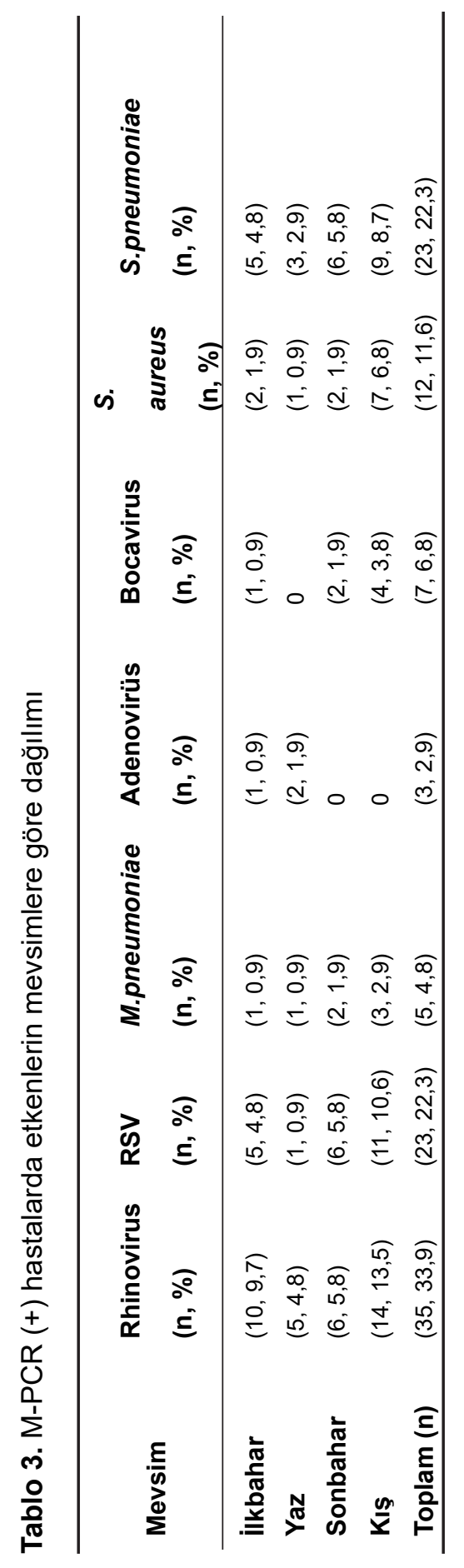


Birleşik Devletleri'nde en sık saptanan virüsler Influenza virüs, RSV ve Parainfluenza virüs iken [27], Fransa'da yapılan çalışmalar, H.metapneumovirus ve RSV' nin en yaygın olduğunu göstermiştir [28]. İnfluenza virüs, RSV ve Rhinovirüs, Çin'in çoğu bölgesinde solunum yolu enfeksiyonlu çocuklar arasında en sık saptanan solunum virüsleri olmuştur [10]. Rusya' nın batı kesiminde ise RSV, Rhinovirüs, Parainfluenza virüs ve İnfluenza virüs'ün anlamlı olarak saptandığı görülmüştür [29].

Çalışmamızda; S.pneumoniae bakteriyel etkenlerden, tek veya çoklu enfeksiyonlarda dahil olmak üzere en sık saptanan bakteriyel etken olup onu S.aureus izlemektedir. Bu sonuçlar literatür ile benzer oranlarda idi [30]. Çalışmamızda $H$. Parechovirus ve $H$. İnfluenza'nın hiç saptanmaması ise dikkat çekiciydi.

Sonuç olarak; araştırmamızın sınırlı boyutu ve tek bir merkeze kısıtlaması olmasına rağmen, çalışmamızda geniş bir etken patojen türü saptanmıştır. Çalışmamızda; özellikle kış aylarında akut alt solunum yolu enfeksiyonu etyolojisinde viral patojenlerin etkili olduğunu ve viral etkenlerden de en sık etkenin Rhinovirüsler olduğunu saptadık.

Solunum yolu enfeksiyonları patojenlerini saptamada M-PCR yöntemini araştıran çok az araştırma vardır. Hızıı ve pratik oluşu, tanıyı erken dönemde koyarak gereksiz antibiyotik kullanımını önleme açısından önemli olması nedeniyle, bu konu ile ilgili daha çok araştırmaya intiyaç vardır.

Çıkar ilişkisi: Yazarlar çıkar ilişkisi olmadığını beyan eder.

\section{Kaynaklar}

1 Verani JR, McCracken J, Arvelo W, et al. Surveillance for hospitalized acute respiratory infection in Guatemala. PLoS One 2013;8:e83600. https://doi.org/10.1371/ journal.pone. 0083600

2. Krause JC, Panning M, Hengel H, Henneke P. The role of multiplex PCR in respiratory tract infections in children. Dtsch Arztebl Int 2014;111:639-645. https:// doi.org/10.3238/arztebl.2014.0639

3. Lam WY, Yeung AC, Tang JW, et al. Rapid multiplex nested PCR for detection of respiratory viruses. J Clin Microbiol 2007;45:3631-3640. https://doi.org/10.1128/ JCM.00280-07
4. Lode HM. Managing community-acquired pneumonia: a European perspective. Respir Med 2007;101:18641873. https://doi.org/10.1016/j.rmed.2007.04.008

5. Strålin K. Usefulness of aetiological tests for guiding antibiotic therapy in community-acquired pneumonia. Int J Antimicrob Agents 2008;31:3-11. https://doi. org/10.1016/j.jiantimicag.2007.06.037

6. Bharaj P, Sullender WM, Kabra SK, et al. Respiratory viral infections detected by multiplex PCR among pediatric patients with lower respiratory tract infections seen at an urban hospital in Delhi from 2005 to 2007. Virol J 2009;6:89. https://doi.org/10.1186/1743422X-6-89

7. Bosphore Respiratory Pathogens Panel Kit, Available

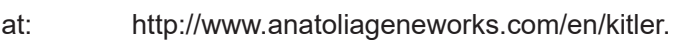
asp?id=208\&baslik=Bosphore. Accessed September 23, 2018

8. Andrews D, Chetty Y, Cooper BS, et al. Multiplex PCR point of care testing versus routine, laboratory-based testing in the treatment of adults with respiratory tract infections: a quasi-randomised study assessing impact on length of stay and antimicrobial use. BMC Infectious Diaseases 2017;17:671. https://doi.org/10.1186/ s12879-017-2784-z

9. Saarela E, Tapiainen T, Kauppila J, et al. Impact of multiplex respiratory virus testing on antimicrobial consumption in adults in acute care: a randomized clinical trial. Clin Microbiol Infect 2020;26:506-511. https://doi.org/10.1016/j.cmi.2019.09.013

10. Esposito S, Daleno C, Prunotto G, et al. Impact of viral infections in children with community-acquired pneumonia: results of a study of 17 respiratory viruses. Influenza Other Respir Viruses 2013;7:18-26. https:// doi.org/10.1111/j.1750-2659.2012.00340.x

11. Dong $\mathrm{W}$, Chen $\mathrm{Q}, \mathrm{Hu} \mathrm{Y}$, et al. Epidemiological and clinical characteristics of respiratory viral infections in children in Shanghai, China. Arch Virol 2016;161:19071913. https://doi.org/10.1007/s00705-016-2866-z

12. Kurskaya O, Ryabichenko $T$, Leonova $N$, et al. Viral etiology of acute respiratory infections in hospitalized children in Novosibirsk City, Russia (2013-2017). 2018;13:e0200117. https://doi.org/10.1371/journal. pone. 0200117

13. Bonzel L, Tenenbaum $\mathrm{T}$, Schroten $\mathrm{H}$, Schildgen $\mathrm{O}$, Schweitzer Krantz S, Adams O. Frequent detection of viral coinfection in children hospitalized with acute respiratory tract infection using a real-time polymerase chain reaction. Pediatr Infect Dis J 2008;27:589-594. https://doi.org/10.1097/INF.0b013e3181694fb9

14. van der Zalm MM, van Ewijk BE, Wilbrink B, Uiterwaal C, Wolfs $T$, van der Ent C. Respiratory pathogens in children with and without respiratory symptoms. J Pediatr 2009;154:396-400. https://doi.org/10.1016/j. jpeds.2008.08.036 
15. Huijskens EG, Biesmans RC, Buiting AG, Obihara $\mathrm{CC}$, Rossen JW. Diagnostic value of respiratory virus detection in symptomatic children using real-time PCR. Virol J 2012;9:276. https://doi.org/10.1186/1743422X-9-276

16. Kwofie TB, Anane YA, Nkrumah B, Annan A, Nguah SB, Owusu M. Respiratory viruses in children hospitalized for acute lower respiratory tract infection in Ghana. Virol J 2012;9:78. https://doi.org/10.1186/1743-422X-9-78

17. Bicer S, Giray T, Çöl D, et al. Virological and clinical characterizations of respiratory infections in hospitalized children. Ital J Pediatr 2013;39:22. https:// doi.org/10.1186/1824-7288-39-22

18. Huang G, Yu D, Mao N, et al. Viral etiology of acute respiratory infection in Gansu Province, China, 2011. PLoS One 2013;8:e64254. https://doi.org/10.1371/ journal.pone.0064254

19. Goka EA, Vallely PJ, Mutton KJ, Klapper PE. Single and multiple respiratory virus infections and severity of respiratory disease: a systematic review. Paediatr Respir Rev 2014;15:363-370. https://doi.org/10.1016/j. prrv.2013.11.001

20. Aydemir Y, Aydemir O, Pekcan S, Özdemir M. Value of multiplex PCR to determine the bacterial and viral aetiology of pneumonia in school-age children. Paediatrics and International Child Health 2015;37:2934. https://doi.org/10.1080/20469047.2015.1106080

21. Akçalı S, Yılmaz N, Güler Ö, Şanlidağ T, Anıl M. Alt solunum yolu enfeksiyonu olan çocuklarda solunum yolu viral etkenlerinin sıklığı. Türk Pediatri Arşivi 2013;48:215-220. https://doi.org/10.4274/tpa.493

22. Sancaklı Ö, Yenigün A, Kırdar S. Alt solunum yolu enfeksiyonunda nazofaringeal örneklerde polimeraz zincir reaksiyonu sonuçları. Çocuk Enfeksiyon Derg 2012;6:84-89. https://doi.org/10.5152/ced.2012.51

23. Torun SH, Somer A, Kanturvardar M, Badur S, Salman N, Yekeler E. Respiratory viruses; today's troubled agents, candidates for marker of diagnosis and prognosis. Indian J 2013;3:1-6. https://doi. org/10.36106/ijar

24. Qui J, Söderlund Venermo M, Young NS. Human parvoviruses. Clin Microbiol Rev 2017;30:43-113. https://doi.org/10.1128/CMR.00040-16

25. Calvo C, Pozo F, García García ML, et al. Detection of new respiratory viruses in hospitalized infants with bronchiolitis: a three-year prospective study. Acta Paediatr 2010;99:883-887. https://doi.org/10.1111/ j.1651-2227.2010.01714.x

26. Jacques $\mathrm{J}$, Moret $\mathrm{H}$, Renois $\mathrm{F}$, Lévêque $\mathrm{N}$, Motte $\mathrm{J}$, Andréoletti L. Human bocavirus quantitative DNA detection in French children hospitalized for acute bronchiolitis. J Clin 2009;58:408-413. https://doi. org/10.1016/j.jcv.2008.05.010
27. Falchi A, Turbelin C, Andreoletti L, et al. Nationwide surveillance of 18 respiratory viruses in patients with influenzalike illnesses. A pilot feasibility study in the French Sentinel network. J Med Virol 2011;83:14511457. https://doi.org/10.1002/jmv.22113

28. Ju X, Fang Q, Zhang J, Xu A, Liang L, Ke C. Viral etiology of influenza-like illnesses in Huizhou, China, from 2011 to 2013. Arch Virol 2014;159:2003-2010. https://doi.org/10.1007/s00705-014-2035-1

29. Iroh Tam PY. Approach to common bacterial infections Virol 2008;43:142-147. https://doi.org/10.1016/j. pcl.2012.12.009

30. Hasman H, Pachucki CT, Unal A, et al. Aetiology of influenza-like illness in adults includes parainfluenzavirus type $4 . \mathrm{J}$ Med Microbiol: community-acquired pneumonia. Pediatr Clin North Am 2013;60:437-453. https://doi.org/10.1099/ jmm.0.006098-0

Çalışmamı $\quad 06.03 .2020$ tarihinde 2. Uluslararası Dr. Behçet Uz Çocuk Kongresi'nde sözlü sunum olarak sunulmuştur.

Etik kurul onayı: Çalışma için İzmir Dr. Behçet Uz Çocuk Hastalıkları ve Cerrahisi Eğitim ve Araştırma Hastanesi Klinik Araştırmalar Etik Komitesi tarafından onay alındı (tarih: 24.08.2017, karar no: 2017/10-07).

\section{Yazarların makaleye olan katkıları}

G.I.K. ve Ç.Ö.E. çalışmanın ana fikrini ve hipotezini kurgulamışlardır. G.I.K. ve E.G. teoriyi geliştirmiş, gereç ve yöntem bölümünü düzenlemişlerdir. Sonuçlar kısmınındaki verilerin değerlendirmesini G.I.K. ve Ö.B. yapmışlardır. Makalenin tartışma bölümü G.I.K. tarafından yazıımış, Ç.Ö.E., Ö.B. ve E.G. gözden geçirip gerekli düzeltmeleri yapmış ve onaylamıştır. Ayrıca tüm yazarlar çalışmanın tamamını tartışmış ve son halini onaylamıştır. 